Ankara Ecz. Fak. Mec.

11183 (1981)
J. Fac. Pharm. Ankara

11183 (1981)

\title{
Normal ve T Uygulanmış Sıçanlarda Karaciğer Glikojen Düzeyleri ve Fosforilaz Kinaz Aktivitesi
}

The Liver Glycogen Levels and Phosphorilase Kinase Activity in Normal and $\mathbf{T}_{3}$ Treated Rats

\section{S. NEBIOĞLU * D. NEBİOĞLU** D. M. GIBSON*** GíRiş}

Fosforilaz kinaz enzimi glikojen metabolizmasında glikojenolizisi düzenleyen enzimlerdendir. Çeşitli hormonlar, cAMP ve $\mathrm{Ca}^{2+}$ gibi hücresel regülatörler aracılığ 1 ile enzimleri etkileyerek, metabolik fonksiyonları düzenler. $\mathrm{Bu}$ hormonlardan insülin, glukagon ve tiroksinin etküeri glikojen metabolizması üzerinde açıklanmıştır.

\section{MATERYAL VE YÖNTEM}

\section{MATERYAL}

Ditiyotreitol (DTT), Sığır serum albumini (BSA), Sukroz, 1, 2, 4 - aminonaftosülfonik asit (ANSA), $\beta$ - Gliserofosfat (1. derece), Amiloglukosidaz, Adenozin 5'-trifosfat (disodyum tuzu, kristal, 1. derece), $\beta$ - nikotinamid adenin dinükleotid (III. derece), Glukoz - 6 - fosfat dehidrogenaz (Tip XXI), Hekzökinaz (Tip C - 300), $\beta$ - merkaptoetanol ( $\beta$-ME), Kafein, Glikojen (Tip III), Glukoz 1 - fosfat (III. derece), 3,3', 5 - triiyodo-L-tironin maddeleri Sigma firmasmdan temin edildi.

Sorval Superspeed RC 2 - B soğuk santrifüj, Beckman Model L ultrasantrifüj, Bioforma derin dondurucu $\left(-70^{\circ} \mathrm{C}\right)$, Gilford UVvisible spektrofotometre, homojenizatörler, atılabilir tüp ve pipet uçları, otomatik Gilson mikropipet kullanıldı.

Materyal olarak 120 - 150 g ağırlıktaki Harlan Wistar sıçan karaciğerleri kullanıldı.

a. Normal ve hipertiroidli deney hayvanlarında glikojen siklusu oluşturulması :

120 - $150 \mathrm{~g}$ ağırlığındaki deney hayvanları günde üçer saat süre ile beslendiler. Saat $03.00-15.00$ arası karanlıkta ve $15.00-03.00$

Redaksiyona verildiği tarih : 8 Ocak 1982

* Biyokimya Kürsüsü, Eczacılık Fakültesi, Ankara Üniversitesi.

** Farmasötik Kimya Kürüsü, Eczacılık Fakültesi, Ankara Üniversitesi.

*** Department of Biochemistry, Medical School, Indiana University, USA.

183 


\section{S. NEBİOĞLU, D. NEBİOĞLU, D. M. GIBSON}

aras1 aydınlıkta birak1lan deney hayvanları saat $7.00-10.00$ arasında normal yem ile beslendiler. İçme suları kafeslerinde her zaman mevcuttu. Deney hayvanları bu tür beslenme şekline 1 hafta süre ile alıştırıldılar. Bir hafta sonra saat 7.00, $10.00,13.00$ ve 16.00 da sıçanlar öldürülerek karaciğer örnekleri alındı. Karaciğer örneklerinin alındığ 1 gün beslenme yine normal olarak 7.00 - 10.00 arasında yapıld1. Ayrica bu guruba paralel olarak bir gurup deney hayvanına da birinci gün beslenmeden hemen sonra $1 \mu \mathrm{g} / \mathrm{g}$. vüc. ağ. dozda enjeksiyon yapılarak hipertiroidi oluşturuldu. Enjeksiyonun yapıldığı gün ve ertesi gün yine aynı saatlerde deney hayvanları öldürülerek karaciğer örnekleri alındı.

\section{Karaciğer dokusunda glikojen düzeylerinin saptanması :}

1 - Glukoz üzerinden hekzokinaz yöntemi ile karaciğerlerden alınan örneklerde glikojen düzeyleri saptandı (1).

2 - Elektron mikroskopisi ile glikojen dağılımının saptanmas1 yapıldı. Deney hayvanlarından alınan karaciğer kesitleri PAS reaksiyonu ile boyanarak, kesitler elektron mikroskopisinde incelendi. Glikojen birikimi ve tüketimi bu şekilde incelenerek saptand.

\section{c. Karaciğer ekstresinde Fosforilaz b kinaz aktivitesi:}

1 - Fosforilaz b kinaz aktivitesinin saptanması için karaciğer ekstreleri hazırland. Tampon olarak pH 7.4 deki $250 \mathrm{mM}$ Sukroz, $10 \mathrm{mM} \mathrm{PO}_{4}, 0.5 \mathrm{mM}$ DTT seçildi (2).

2 - Fosforilaz b kinaz aktivitesinin saptanması için VANDENHEEDE tarafından geliştirilen yöntem kullanıldı (2). Inkübasyon ortam $10 \mathrm{mM} \mathrm{MgAc}_{2}, 1 \mathrm{mM}$ ATP, $50 \mathrm{mM} \mathrm{NaF}, 10 \mathrm{mM} \mathrm{P}_{4}$ $1 \mathrm{mM}$ cAMP, $0.45 \mathrm{mM}$ EGTA/ $0.3 \mathrm{mM} \mathrm{CaCl}_{2}, 10 \mathrm{mg} / \mathrm{ml} \mathrm{Ph} \mathrm{b}$ ve $20 \mu \mathrm{l}$ örnek ekstre son hacım $200 \mu \mathrm{l}$ olacak şekilde karıştırıldı. Reaksiyon, $\mathrm{Ph}$ b ilavesi ile başlatıld 1 ve 10 dakika $30^{\circ} \mathrm{C}$ de inkübe edildi. Reaksiyon, $20 \mu \mathrm{l}$ lik örneklerin inkübasyon ortamından alınıp, buz içinde bekleyen $\mathrm{pH} 6.8$ deki $10 \mathrm{mM} \beta$-gliserofosfat, $20 \mathrm{mM}$ $\mathrm{NaF}, 45 \mathrm{mM} \beta$ - merkapto etanol tampon karışımında $20 \mathrm{kez}$ seyreltilmesi ile durduruldu. Bu dilüsyondan $100 \mu \mathrm{l}$ lik örnekler alınarak bilinen fosforilaz'a tayini yöntemi uyguland1 (3).

\section{BULGULAR}

Glikojenin enzimatik saptanmasında $\mathbf{T}_{3}$ uygulanmış deney hayvanlarında ikinci gün beslenme üe birlikte glikojen artışı olmakta, ancak bu düzey hiçbir zaman normal deney hayvanlarındaki gliko- 
Normal ve T Uygulanmış Sıçanlarda

jen düzeyine erişememektedir. Karaciğer doku kesitleri elektron mikroskobisi ile incelendiğinde glikojenin tüketimi aynı şekilde izlenebilmektedir.

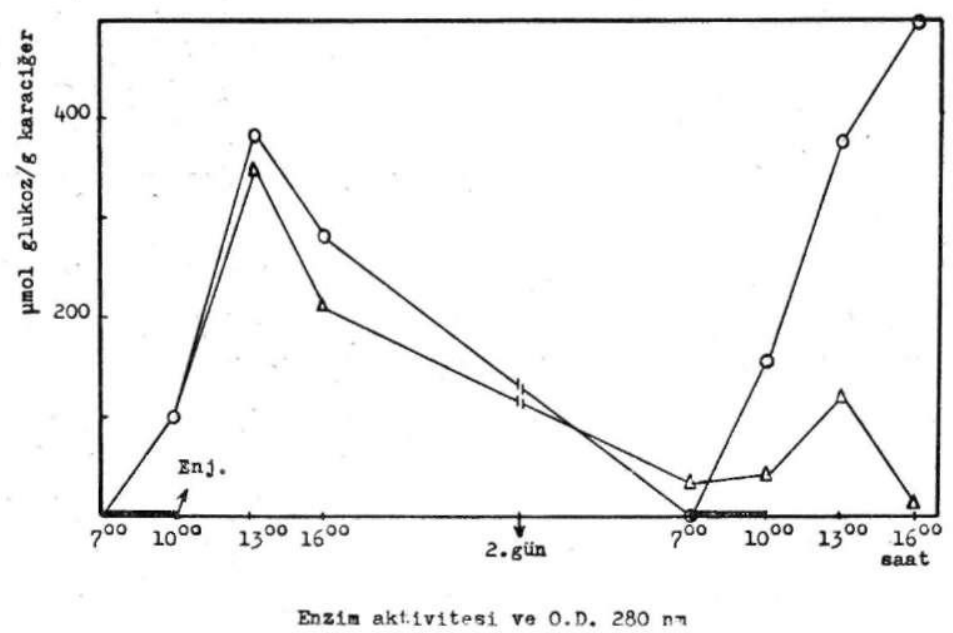

Şek. - 1 : Günde üç saat normal yemle beslenen deney hayvanlarında açlık, tokluk ve hipertiroid durumlarına bağlı olarak değişen karaciğer glikojen düzeyleri. ( $₫$ a) Beslenme zamanı : 7.00 - 10.00. Enjeksiyon : Deneyin birinci gününde saat 10.00 da $1 \mu$ g/g vüc. ăg. I, P. olarak. Kontrol gurubuna $\% 0.9$ $\mathrm{NaCl}$ enjekte edilmiştir. ( $\mathrm{O}-\mathrm{O})$ Kontrol gurubu, $(\Delta-\Delta)$ Hipertiroidli gurup. Her nokta için 2 deney hayvanı kullanılmıştır. Deney üç kez, ayrı gurup hayvan kullanılarak tekrarlanmıştır.

Şekil 1 de görüldüğü gibi beslenme bittikten 3 saat sonra karaciğer glikojen tanecikleri normal deney hayvanlarında iyice yoğunlaşmış iken, $\mathbf{T}_{3}$ enjekte edilmiş hayvanlarda daha az bir yoğunluk göstermektedir (Resim : 1 - 2). Beslenme bittikten 6 saat son- 


\section{S. NEBİOĞLU, D. NEBİOĞLU, D. M. GIBSON}
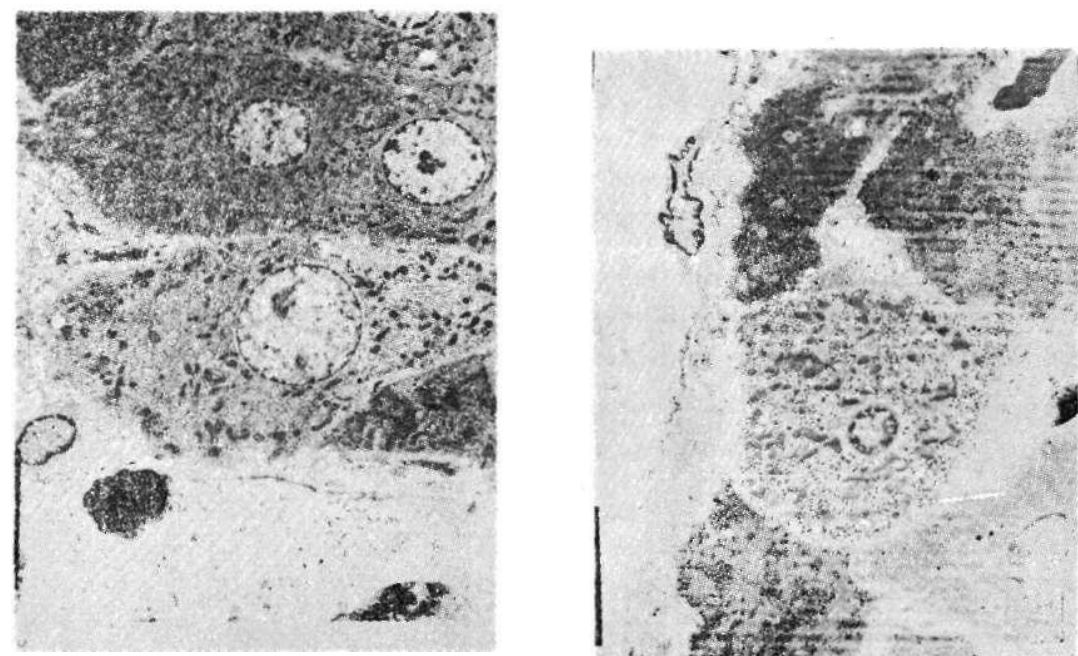

Resim : 1 - 2 Beslenme bittikten 3 saat sonra normal (1) ve $T_{3}$ enjekte edilmiş (2) deney hayvanında Glikojen tanecikleri. $7000 \mathrm{x}$.

ra ise normal deney hayvanlarının karaciğerlerindeki glikojen taneciklerinin sayısı en üst düzeye yükselmiş olmasına karşın, $\mathrm{T}_{3}$ enjekte edilmiş hayvanlardaki glikojen tanecikleri hemen tamamen kaybolmuştur. (Resim : 3-4). Bu saatte normal karaciğerden alman
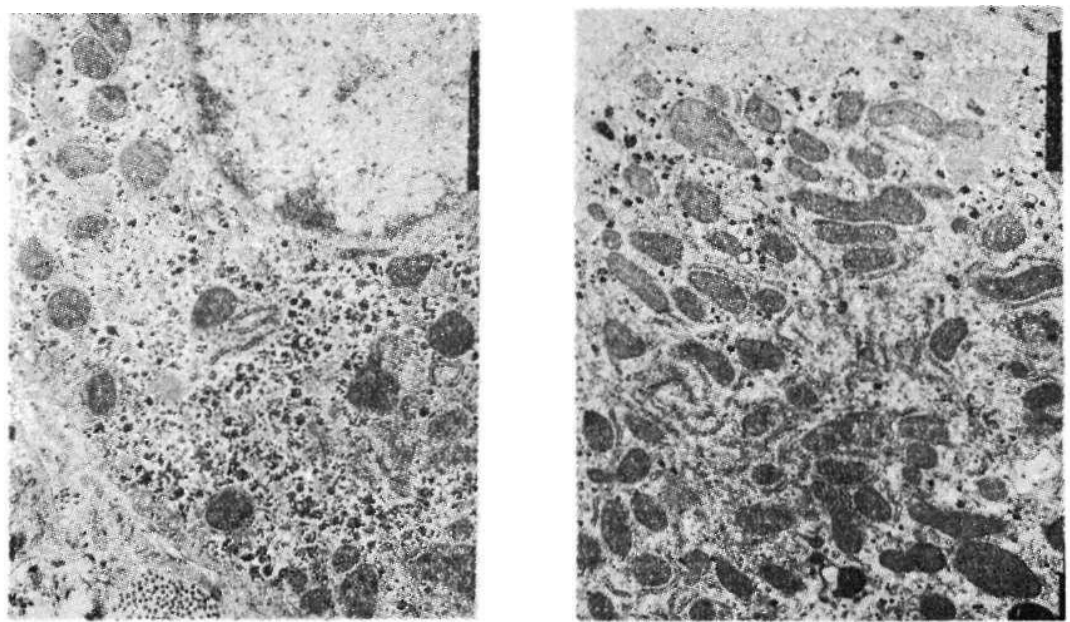

Resim : 3 - 4 Beslenme bittikten 6 saat sonra normal (3) ve $T_{3}$ enjekte edilmiş (4) deney hayvanlarında Glikojen tanecikleri. 27.700 x. 


\section{Normal ve T Uygulanmış Sıçanlarda}

kesitler diastaz ile muamele edildiğinde bütün glikojen taneciklerinin kaybolduğu açılıkla görülmektedir (Resim : 5).

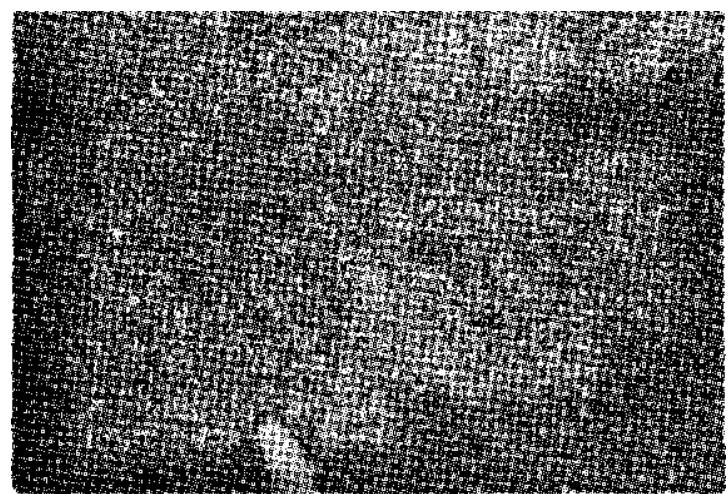

Resim : 5 Beslenme bittikten 6 saat sonra normal karaciğerden alınan kesitler diastaz ile muamele edilmişlerdir.

Elde edilen karaciğer ekstrelerinde fosforilaz kinaz aktivitesi glikojen profiline uygun bir gelişim göstermektedir. (Şekil : 2). Enzim aktivitesi glikojen tüketiminin arttığ 1 saatlerde yükselmiş, enzim aktivitesinin düştüğü anda ise glikojen düzeyi yükselmiştir.

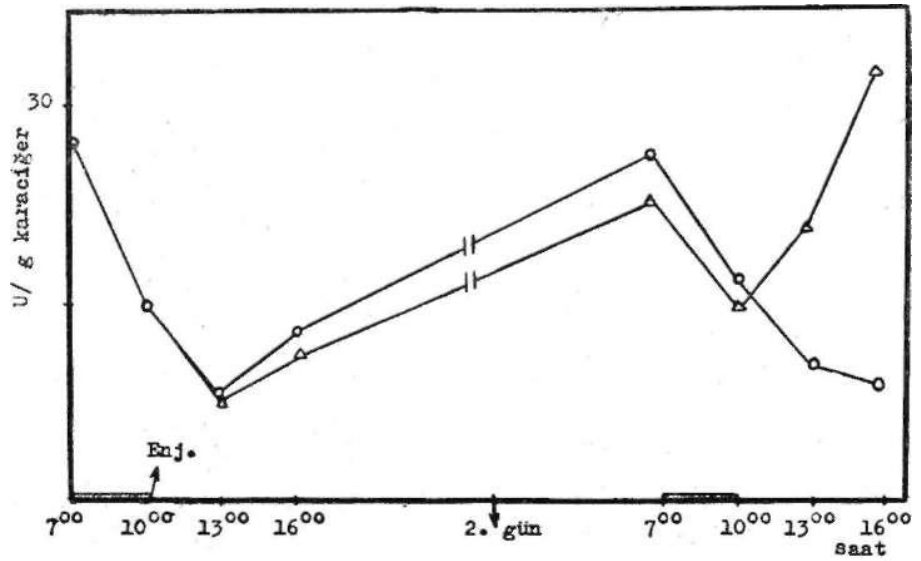

Şek. - 2 : Aynı deney hayvanlarında karaciğer fosforilaz kinaz aktivitesi. $(\mathrm{O}-\mathrm{O})$ Kontrol gurubu, $(\Delta-\Delta)$ Hipertiroidli gurup. 


\section{S. NEBİoĞLU, D. NEBİOĞLU, D. M. GIBSON}

\section{SONUÇ VE TARTIŞMA}

Karaciğerde glikojen pelletini glikojen metabolizması enzimleri oluşturmaktadır (4). Diastaz ile parçalanıp, boyanması önlenen taneciklerdeki fosforilaz b kinaz ve glikojen sentaz gibi, glikojene bağlı enzimler de ortadan kaybolmaktadır.

Glikolitik enzimlerden fosforilaz b kinaz glikojen metabolizmasını çeşitli hormonlara bağlı olarak düzenlemektedir. Açlıkla birlikte salgılanmaya başlayan glukagon, adenil siklazı aktive etmekte ve dolayısı ile hücre cAMP düzeyi yükselmektedir (5). cAMP bir dizi reaksiyonla fosforilaz kinazı aktive etmekte ve glikojenolizis meydana gelmektedir $(6,7)$. Beslenme yeniden başladığında kandaki glukoz düzeyi yükselip, $\mathrm{Ca}^{2}+$ un hücrelere iletimi artar (8) ve bununla birlikte protein kinazların aktivasyonu ile $(9,10)$ insülin salınımı artar, cAMP düzeyi düşerek protein kinazın fosforilaz kinazı aktive etmesi önlenir $(11,12)$. Ayrıca glukozun hücre içine girerek fosforlanması sağlanır. Tiroksin hormonu glikojen tüketimi şeklindeki etkisini fosforilaz kinaz enzimi üzerinde gösterdiği düzenleyici etki ile sağlar.

\section{ÖZET}

Normal ve hipertiroidli sıçanların karaciğer kesitlerinde glikojen düzeyleri, elektron mikroskopisi ile incelendi. Karaciğer ekstrelerindeki fosforilaz kinaz aktivitesi glikojen birikim ve tüketmine uyumlu olarak değişmektedir.

\section{SUMMARY}

The Glycogen levels have been investigated by electron microscopy in liver slices of normal and hyperthyroid rats. The activity of phosphorilase kinase in liver extracts alters concerted to Glycogen accumulation and depletion.

\section{LITERATÜR}

1. Bergmeyer H. U. : Methods of Enzymatic Analysis, Acad, Press, s. 59, (1965).

2. Vendenheede J. R., Kenpens S., De Wulf H. : Inactivation and Reactivation of Liver Phosphorilase Kinase. Biochem. Biophys. Acta. 481, 463 (1977).

3. Stalmans W., De Wulf H., Hue L., Hers H. G. : The Sequential Inactivation of Glycogen Phosphorilase and Activation of Glycogen Synthase in Liver after Administration of Glucose to Mice and Rats. The Mechanism of Hepatic Treshold to Glucose. Eur. J. Bichem. 41, 127 (1974). 
Normal ve T Uygulanmış Sıçanlarda

4. Harper J. F., Cheung W. Y., Wallace R. W., Huang H. L., Levine S. N., Steiner A. L., : Localisation of Calmodulin in Rat Tissues. Proc. Natl. Acad. Sci. USA. 77, 1,366 (1980).

5. Shimazu T., Amakawa A. : Regulation of Glycogen Metabolism in Liver by the Autonomic Nervous System VI. Possible Mechanism of Phosphorilase Activation by the Splanchnic Nerve. Biochem. Biophys. Acta. 385, 242 (1975).

6. Cohen P, : The Role of Cyclic AMP-Dependent Protein Kinase in the Regulation of Glycogen metabolism in Mammalian Skeletal Muscle Curr. Top. CeU. Beg. 14, 117 (1978).

7. Van De Werve G., Hue L., Hers H. G. : Hormonal and Ionic Control of the Glycogenolytic Cascade in Rat Liver. Biochem. J. 162, 135 (1977).

8. Dean P. M., Matthews E. K. : Glucose Induced Electrical Activity in Pancreatic Islet Cells. J. Physiol (London). 210, 225 (1970).

9. Malaise W. J.: Insulin Secretion : Multifactoral Regulation for a Single Process of Release. Diabetologia 9, 167 (1973).

10. Schubart U. K., Erlichman J., Eischer N. : The Role of Calmodulin in the Regulation of Protein Phosphorilation and Insulin Release in Hamster Insulinoma Cells. J. Biol. Chem. 255, 4120 (1980).

11. Curnow R. T., Rayfield E. J., George D. T., Zenser T. V., De Rubertis F. : Control of Hepatic Glycogen Metabolism in the Rhesus Monkey : Effect of Glucose, Insulin and Glucagon Administration. Am. J. Physiol. 228, 80 (1975).

12. Miller T. B. J., Larner J. : Mechanism of Control of Hepatic Glycogenesis by Insulin. J. Biol. Chem. 248, 3483 (1973). 